\title{
Asymptomatic Hypercalcemia due to Cavitary Pulmonary Tuberculosis: A Case Report
}

\author{
Soheil Ebrahimpour ${ }^{1}$, Zeinab Darabi Ahangar ${ }^{1}$, Mahmoud Sadeghi-Haddad-Zavareh"1, \\ Zeinab Mohseni Afshar ${ }^{2}$, Mehran Shokri ${ }^{1}$, Arefeh Babazadeh ${ }^{1}$ \\ ${ }^{1}$ Infectious Diseases and Tropical Medicine Research Center, Health Research Institute, \\ Babol University of Medical Sciences, Babol, Iran \\ ${ }^{2}$ Clinical Research Development Center, Imam Reza Hospital, Kermanshah University of Medical Sciences, \\ Kermanshah, Iran
}

\section{SUMMARY}

Hypercalcemia in granulomatous diseases as tuberculosis (TB) is uncommon. We describe a case of a 21year-old male whose serum calcium level was $14 \mathrm{mg} / \mathrm{dL}$ at the time of admission. Chest imaging revealed a cavity at the top of both lungs as well as the closure of the right laberal angle. The sputum smears and culture were evaluated regarding Mycobacterium tuberculosis and the findings of the smear and culture were reported as positive. As the values of creatinine were increased, renal failure had to be investigated. Both pathological mechanisms appear to affect the renal function. The anti-TB treatment included isoniazid $5 \mathrm{mg} / \mathrm{kg}$, rifampicin 10 $\mathrm{mg} / \mathrm{kg}$ and pyrazinamide $20 \mathrm{mg} / \mathrm{kg}$ once daily for two months and then the therapy continued with isoniazid and pyrazinamide up to eight months. The patient also received hydration, loop diuretics, and prednisolone (20 $\mathrm{mg}$ per day). One week after the introduction of the corticosteroid therapy, the patient's serum creatinine and calcium (Ca) levels decreased ( $4 \mathrm{mg} / \mathrm{dL}$ to $2 \mathrm{mg} / \mathrm{dL}$, and $14 \mathrm{mg} / \mathrm{dL}$ to $10 \mathrm{mg} / \mathrm{dL}$, respectively).

Hypercalcemia, renal failure, interstitial nephritis, and proteinuria are rare in pulmonary tuberculosis but should be considered as severe complications. Therefore, hypercalcemia should be first controlled by hydration or some steroids along with the treatment of $\mathrm{TB}$, and introduction of loop diuretics and nutritional constraints.

Key words: hypercalcemia, renal failure, tuberculosis 


\section{INTRODUCTION}

Tuberculosis (TB) is a dangerous disease that threatens the health of a community (1). In rare cases, granulomatous diseases such as sarcoidosis, fungal infections and TB can be a secondary cause of hypercalcemia and hypercalciuria, which are asymptomatic in most cases $(2,3)$. The prevalence of hypercalcemia varies in different parts of the world, ranging from $2 \%$ to $30 \%$ (4). The prevalence of hypercalcemia is reported to be $16 \%$ in patients with $\mathrm{TB}$, and in tropical areas such as Nigeria it amounts to $27.5 \%$ (5). However, this level depends on the level of total vitamin $\mathrm{D}$ and calcium intake. Hypercalcemia is unusual in patients with TB and patients with renal failure, and only a few such cases have been reported so far. The aim of this paper was to present a case without a history of a previous disease, with the symptoms of pulmonary $\mathrm{TB}$, hypercalcemia and renal failure.

\section{CASE REPORT}

A patient was a 21-year-old male student, from Babol, northern Iran, and referred to the history of productive cough and fever in duration of six months. The patient also mentioned $10 \mathrm{~kg}$ weight loss during this period but had no sign of shortness of breath, night sweats, and chest pain. During this period, the patient had an outpatient visit to a doctor and was treated with oral antibiotics but did not recover. The patient did not mention the history of some previous disease, and was neither a smoker nor an addict.

The examination showed fever above $38{ }^{\circ} \mathrm{C}$; the patient had high blood pressure $(140 / 90 \mathrm{mmHg})$ and sinus tachycardia $(P R=98)$. Oxygen saturation without nasal oxygen was $98 \%$. The conjunctiva was pale. In the lung-eardrum pathway, the loss of sound was noticed in the right lung. In the chest X-ray (CXR), a cavity was seen at the top of both lungs, and the right lateral angle was closed (Figure 1).

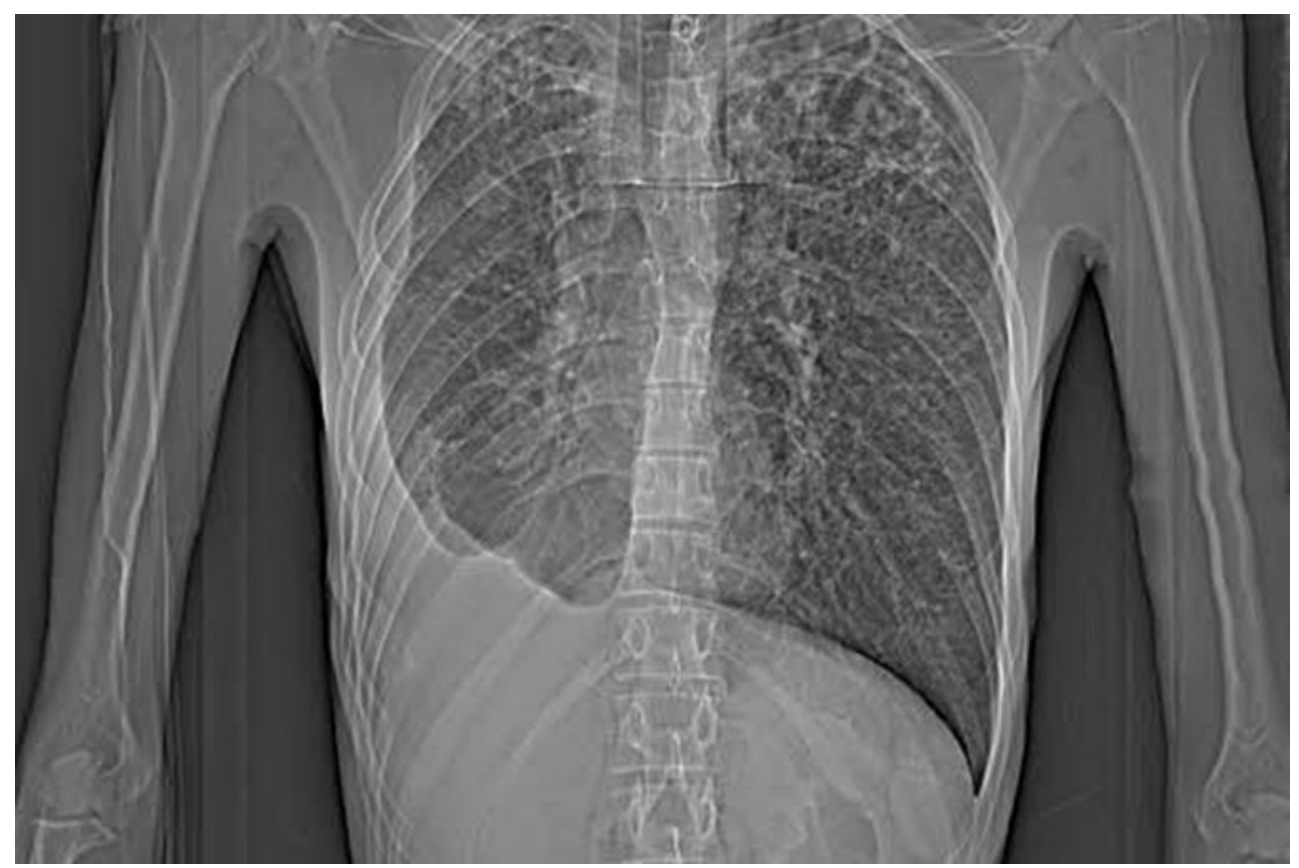

Figure 1. The chest X-ray (CXR) shows the cavity on the top of both lungs in which the right lateral angle was closed

Spiral computed tomography (CT) scan without contrast medium showed pleural calcification with pleural effusion and evidence of a decrease in the size of the right hemithorax. Moreover, calcified lymph nodes were located in the right bronchovascular area. Two nodules, $18 \mathrm{~mm}$ and $37 \mathrm{~mm}$ in size, with corneal calcification, 
were observed in the pleura, and large cavitary lesions were observed at the top of both lungs in addition to tree-in-bud opacities, patchy ground-glass opacities, and synthetic lobar nodules (Figure 2 and 3).

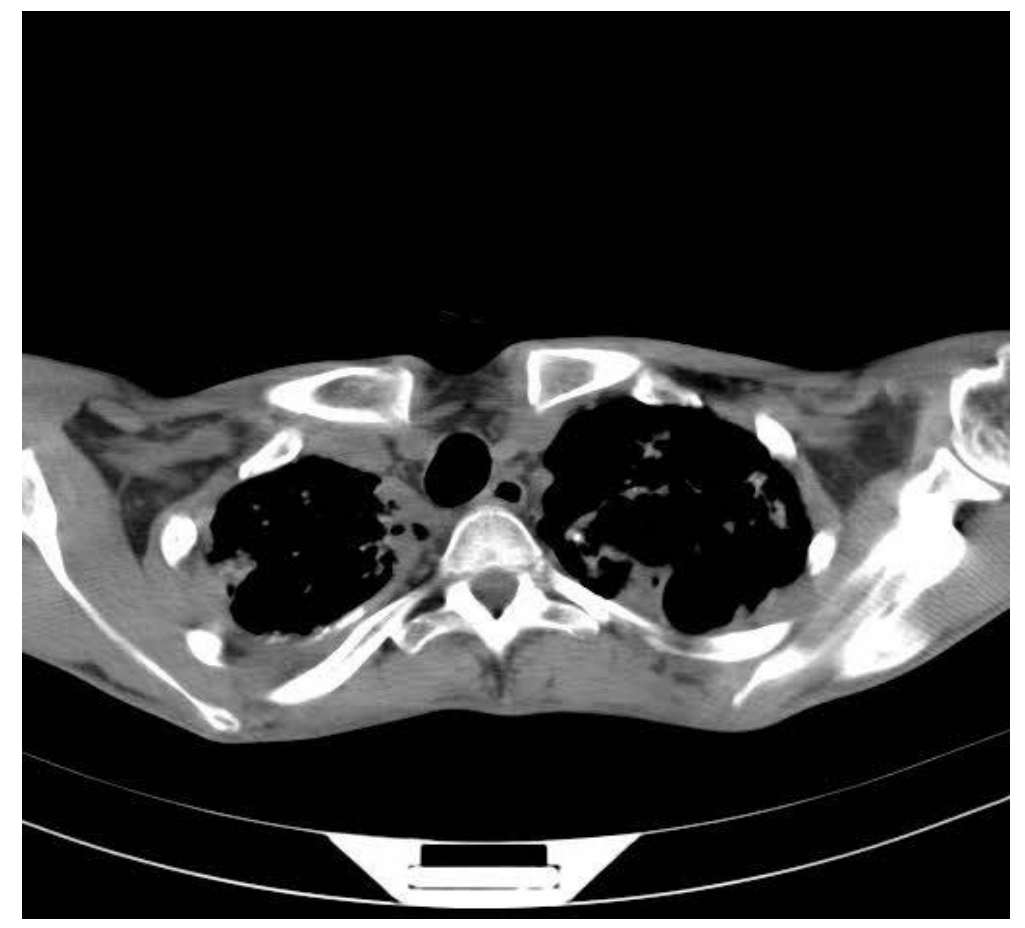

Figure 2. The spiral computed tomography (CT) scan without contrast shows a pleural calcification with pleural effusion and evidence of a decrease in the size of the right hemithorax

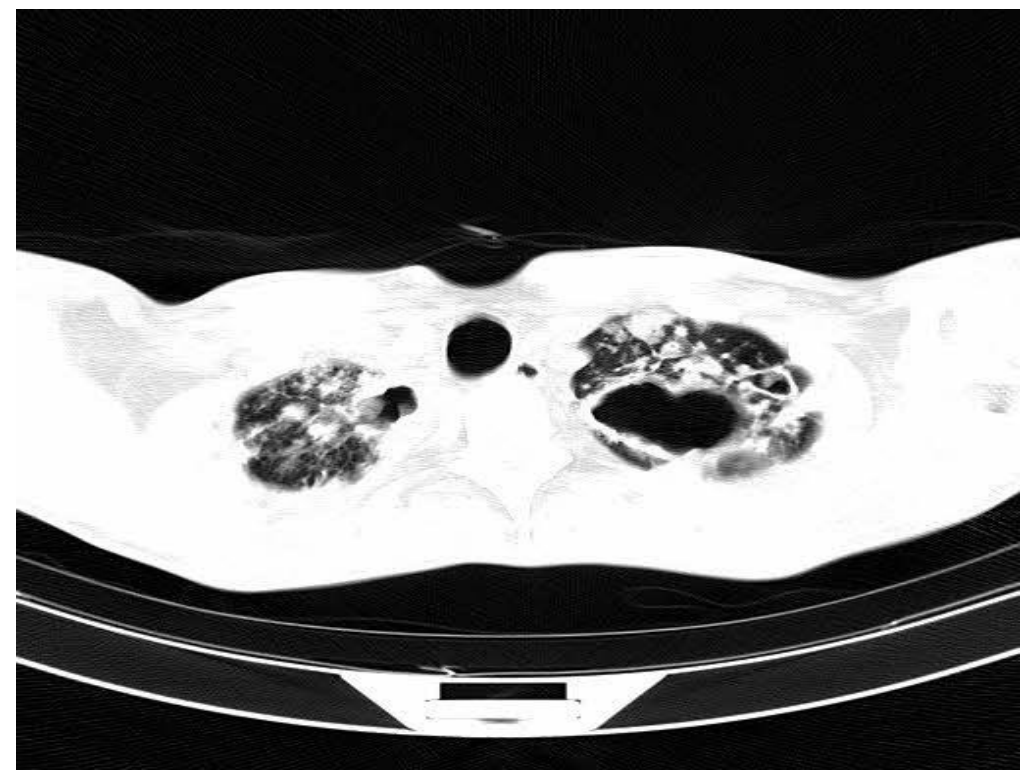

Figure 3. Computed tomography (CT) scan shows calcified lymph nodes in the right bronchovascular area, with corneal calcification in the pleura and large cavitary lesions on the top of both lungs, as well as tree-in-bud opacities, patchy ground-glass opacities, and synthetic lobar nodules 
Based on the radiological patterns and epidemiological conditions, the findings strongly suggested the existence of tuberculosis. The patient's laboratory results were as follows: leukocytosis $\left(\mathrm{WBC}=12.500\right.$ cells $\left./ \mathrm{mm}^{3}\right)$; anemia $(\mathrm{Hb}=8.6 \mathrm{~g} / \mathrm{dL})$ with mean corpuscular volume (MCV) - 82; platelet count (PLT) - 478,000/ $\mathrm{mm}^{3}$; C-reactive protein (CRP) - $68 \mathrm{mg} / \mathrm{L}$; erythrocyte sedimentation rate (ESR) - $110 \mathrm{~mm} / \mathrm{hr} ; \mathrm{Na}, 122 \mathrm{mmol} / \mathrm{L}$ and creatinine $(\mathrm{Cr}): 3.8 \mathrm{mg} / \mathrm{dL}$. In the following tests, calcium (Ca), $10.05 \mathrm{mg} / \mathrm{dL}$, phosphorus, $4.5 \mathrm{mg} / \mathrm{dL}$; albumin (ALB), 3.8 $\mathrm{g} / \mathrm{dL} ; 25 \mathrm{OHVitD3}, 71 \mathrm{nmoL} / \mathrm{L}$, and in the urinalysis, specific gravity (SG), 10.3 and $\mathrm{pH} 7$ with proteinuria 2+ were reported. Due to the suspicion of pulmonary TB, the patient was hospitalized in an isolated room with negative pressure. The sputum smears and culture were evaluated regarding Mycobacterium tuberculosis, and the findings of the smear and culture were reported as positive. The anti-TB treatment included isoniazid $5 \mathrm{mg} / \mathrm{kg}$, rifampicin $10 \mathrm{mg} / \mathrm{kg}$ and pyrazinamide $20 \mathrm{mg} / \mathrm{kg}$ once daily for two months and then therapy continued with isoniazid and pyrazinamide up to eight months, (with adjustments according to glomerular filtration rate (GFR)). Considering the increased values of creatinine, the patient was also examined for renal failure. In the ultrasound of the kidney and urinary tract, the right kidney and the left kidney were reported to be $100 \mathrm{~mm}$ and $105 \mathrm{~mm}$ in diameter, respectively; parenchymal echo patterns of both kidneys were increased. However, no evidence of nephrolithiasis was found. The 24-hour urine specimen results were as follows: protein - $909 \mathrm{mg}$, volume $-2,250 \mathrm{ml}$ and $\mathrm{Cr}-1100 \mathrm{mg} / \mathrm{dL}$. The test results for HIV were negative. Smear examination of early morning urine specimen regarding AFB was also negative, which was confirmed in three consecutive analyses.

The patient was also examined regarding autoimmune diseases and the complement levels were normal. The antinuclear antibody (ANA), antiglomerular basement membrane (GBM), anti-double stranded DNA (anti-dsDNA), and anti-neutrophil cytoplasmic antibodies (ANCA) were also within the normal range. Ultimately, in a re-examination of the patient in terms of electrolytes, the patient's calcium level was $14 \mathrm{mg} / \mathrm{dL}$; phosphorus - $3.5 \mathrm{mg} / \mathrm{dL}$; 24-hour urine calcium - 390 $\mathrm{mg} / \mathrm{dL}$ (normal, too); intact parathyroid hormone (iPTH) - $9 \mathrm{pg} / \mathrm{mL}$ and $25 \mathrm{OHVitD}-1 \mathrm{ng} / \mathrm{mL}$. Considering the unjustifiable high creatinine and proteinuria levels, and persistently high levels of creatinine after three weeks, the patient then underwent kidney biopsy. Therefore, chronic tubulointerstitial nephritis with mild inflammation was reported in pathological analysis. Considering high calcium levels, normal phosphor, low iPTH, high urine calcium (hypercalcemia), and renal pathology, nephritis was considered in the context of granulomatous disease (tuberculosis), and in addition to anti-TB drugs, the patient received hydration, loop diuretics, and prednisolone at a dose of $20 \mathrm{mg}$ per day. One week after starting the corticosteroid therapy, the patient's creatinine level decreased from $4 \mathrm{mg} / \mathrm{dL}$ to $2 \mathrm{mg} / \mathrm{dL}$, and Ca decreased from $14 \mathrm{mg} / \mathrm{dL}$ to $10 \mathrm{mg} / \mathrm{dL}$. For this reason, the patient was discharged with a recommendation to continue taking the corticosteroid therapy and have monitored the level of calcium for the next two months until the decrease of $\mathrm{Ca}$; the use of nti-TB drugs including isoniazid and pyrazinamide was recommended for the next eight months.

\section{DISCUSSION}

The paper presents the case of a patient with smear-positive cavitary pulmonary tuberculosis, and there were some specific indicators in the patient's tests that pointed to renal failure, proteinuria, and hypercalcemia caused by secondary hyperparathyroidism. It should be noted that renal involvement in tuberculosis is more commonly caused by the hematogenous seeding of bacillus that leads to the destruction of renal glomeruli, the formation of abscess, descending release of the infection to the ureter and bladder, stenosis and obstruction, hydronephrosis, and ultimately renal dysfunction (6-9). As ultrasound examination showed no evidence of renal involvement, other mechanisms had to be considered. Since TB rarely causes glomerulonephritis and interstitial nephritis of the kidney, and although its pathogenesis is not completely clear, nephritis is an immunological phenomenon, at least in some patients (10). In other words, as biopsy was not done, it was not possible to determine the definitive cause. Two possible mechanisms for kidney involvement in the course of tuberculosis were expected. Direct involvement of parenchyma was unlikely due to the negative results obtained in the analysis of urinary smear (repeated for three times), i.e. if we had continued to treat tuberculosis, we would have got a curative treatment cover. However, by adding a corticosteroid to the regimen, significant changes in calcium levels were observed at the calcium level. In some studies, even the polymerase chain reaction (PCR) of kidney biopsy specimens of these patients was negative regarding TB (11). In our patient, interstitial nephritis was reported in the pathology of kidney biopsy, but Mycobacterium tuberculosis was not observed. Another finding in our patient was hypercalcemia, which was not justifiable with regard the interstitial strengthening. 
It was proved that granulomatous diseases such as sarcoidosis, tuberculosis, and fungal infections may cause hypercalcemia due to the extrarenal production of 1, 25 $(\mathrm{OH}) 2 \mathrm{D} 3$ in activated macrophages in granulomas and CD8+ T-cells, which can suppress PTH (12-14). Subsequently, due to the low level of PTH and the presence of hypercalciuria, hypercalcemia was suspected. In other words, by induction of vasoconstriction on renal glomeruli, hypercalcemia may reduce GFR, which can induce nephrolithiasis and nephrocalcinosis in the kidney through hypercalcemia, if it persists. It could be postulated that the increase in creatinine in our patient may be caused by two mechanisms of hypercalcemia and interstitial nephritis. In some studies on the treatment of hypercalcemia using this mechanism, only anti-TB treatment and hydration were mentioned. However, avoiding Ca supplements, dairy products, exposure to sunlight, and ultimately loop diuretics contribute to the normalization of Ca levels. In some cases, it is necessary to introduce corticosteroids in order to control this disorder and restore $\mathrm{Ca}$ and $\mathrm{Cr}$ to the normal levels $(15,16)$.

\section{CONCLUSION}

Hypercalcemia, renal failure, interstitial nephritis, and proteinuria are rare manifestations of pulmonary tuberculosis but should be considered as complications of tuberculosis. Although hypercalcemia is not usually symptomatic in these patients, it can lead to renal failure. Therefore, it should be controlled first by hydration in addition to treatment with anti-TB loop diuretics and nutritional constraints. If not controlled, treatment with steroids should be considered. In the case presented here, both hypercalcemia and interstitial nephritis appear to affect renal failure; thus, several mechanisms should always be taken into consideration.

\section{Acknowledgements}

The authors would like to express their sincere gratitude to the Department of infectious diseases of Babol University of Medical sciences, Iran.

\section{Conflicts of interests}

There are no conflicts of interest. 


\section{References}

1. Pai M, Behr MA, Dowdy D, et al. Tuberculosis. Nat Rev Dis Primers 2016;2:16076.

https://doi.org/10.1038/nrdp.2016.76

2. Shrayyef MZ, DePapp Z, Cave WT, Wittlin SD. Hypercalcemia in two patients with sarcoidosis and Mycobacterium avium intracellulare not mediated by elevated vitamin D metabolites. Am J Med Sci 2011;342:336-40. https://doi.org/10.1097/MAJ.0b013e31822224c3

3. Jacobs TP, Bilezikian JP. Rare Causes of Hypercalcemia. J Clin Endocrinol Metab 2005;90:6316-22. https://doi.org/10.1210/jc.2005-0675

4. Jick S, Li L, Gastanaga VM, Liede A. Prevalence of hypercalcemia of malignancy among cancer patients in the UK: analysis of the Clinical Practice Research Datalink database. Cancer Epidemiol 2015;39:901-7. https://doi.org/10.1016/j.canep.2015.10.012

5. Kavanaugh MJ, Bavaro MF, Barthel RV, Maves RC, Groff HL. Severe Hypercalcemia as the Presenting Sign of Tuberculosis. J Med Cases 2015;6:382-4. https://doi.org/10.14740/jmc2220w

6. Merchant S, Bharati A, Merchant N. Tuberculosis of the genitourinary system-Urinary tract tuberculosis: Renal tuberculosis-Part I. Indian J Radiol Imag 2013;23:46-63.

https://doi.org/10.4103/0971-3026.113615

7. Figueiredo AA, Lucon AM. Urogenital Tuberculosis: Update and Review of 8961 Cases from the World Literature. Rev Urol 2008;10:207-17.

8. Wagaskar VG, Chirmade RA, Baheti VH, Tanwar HV, Patwardhan SK, Gopalakrishnan G. Urinary Tuberculosis with Renal Failure: Challenges in Management. J Clin Diagn Res 2016;10:PC01-PC3. https://doi.org/10.7860/JCDR/2016/16409.7017
9. Wang J, Fan S, Xiao J, Liang C-Z. Renal tuberculosis tends to be low symptoms: how to improve the diagnosis and treatment of renal tuberculosis. Asian J Androl 2016;18:145-6. https://doi.org/10.4103/1008-682X.150839

10. Eastwood JB, Corbishley CM, Grange JM. Tuberculosis and tubulointerstitial nephritis: an intriguing puzzle. Kidney Int 2011;79:579-81. https://doi.org/10.1038/ki.2010.495

11. Sun L, Yuan Q Feng JM, et al. Rapid diagnosis in early stage renal tuberculosis by real-time polymerase chain reaction on renal biopsy specimens. Int J Tuberc Lung Dis 2010;14:341-6.

12. Negri AL, Rosa Diez G, Del Valle E, et al. Hypercalcemia secondary to granulomatous disease caused by the injection of methacrylate: a case series. Clin Cases Miner Bone Metab 2014;11:44-8. https://doi.org/10.11138/ccmbm/2014.11.1.044

13. Rajendra A, Mishra AK, Francis NR, Carey RAB. Severe hypercalcemia in a patient with pulmonary tuberculosis. J Family Med Prim Care 2016;5:509-11. https://doi.org/10.4103/2249-4863.192327

14. Tebben PJ, Singh RJ, Kumar R. Vitamin D-Mediated Hypercalcemia: Mechanisms, Diagnosis, and Treatment. Endocr Rev 2016;37:521-47. https://doi.org/10.1210/er.2016-1070

15. Huang I-H, Wu S-W. Refractory hypercalcemia in a patient with disseminated tuberculosis: A successful case of prolonged treatment with corticosteroid. J Med Sci 2017;37:72. https://doi.org/10.4103/jmedsci.jmedsci 9215

16. Chan JY, Kanthaya M. Hypercalcaemic crisis in an elderly patient with pulmonary tuberculosis. Oxf Med Case Reports 2015;2015:354-7. https://doi.org/10.1093/omcr/omv061 


\title{
Asimptomatska hiperkalcemija usled kavitarne tuberkuloze pluća: prikaz slučaja
}

\author{
Soheil Ebrahimpour ${ }^{1}$, Zeinab Darabi Ahangar ${ }^{1}$, Mahmoud Sadeghi-Haddad-Zavareh ${ }^{1}$, \\ Zeinab Mohseni Afshar ${ }^{2}$, Mehran Shokri ${ }^{1}$, Arefeh Babazadeh ${ }^{1}$ \\ ${ }^{1}$ Istraživački centar za infektione i tropske bolesti, Zdravstveni istraživački institut, \\ Univerzitet medicinskih nauka u Babolu, Babol, Iran \\ ${ }^{2}$ Klinički istraživačko-razvojni centar, Bolnica Imam Reza, Univerzitet medicinskih nauka u Kermanšahu, \\ Kermanšah, Iran
}

\section{SAŽETAK}

Hiperkalcemija kod granulomatoznih bolesti poput tuberkuloze (TB) je retka. U radu je opisan slučaj dvadesetjednogodišnjeg muškarca kod koga je nivo kalcijuma u serumu iznosio $14 \mathrm{mg} / \mathrm{dL}$ u vreme prijema. Snimanje grudnog koša pokazalo je postojanje šupljina u gornjem delu oba plućna krila, dok je desni lateralni ugao bio zatvoren. Kultura i razmaz sputuma na mikroskopskoj pločici analizirani su na prisustvo bacila Mycobacterium tuberculosis i dobijeni rezultati bili su pozitivni. Kako su vrednosti kreatinina bile povećane, krenulo se sa ispitivanjem bubrežne insuficijencije. Oba patološka mehanizma uticala su na bubrežnu insuficijenciju. Anti-TB terapija uključila je primenu isoniazida u dozi od $5 \mathrm{mg} / \mathrm{kg}$, rifampicina u dozi od 10 $\mathrm{mg} / \mathrm{kg}$ i pirazinamida u dozi od $20 \mathrm{mg} / \mathrm{kg}$ jednom dnevno, u trajanju od dva meseca, a potom je terapija nastavljena isoniazidom i pirazinamidom narednih osam meseci. Pacijent je bio hidriran, primio je diuretike Henleove petlje i prednisolon ( $20 \mathrm{mg}$ ). Nedelju dana nakon uvođenja terapije kortikosteroidima nivoi serumskog kreatinina i kalcijuma su se smanjili (od 4 mg/dL na 2 mg/dL i od 14 mg/dL na 10 mg/dL).

Hiperkalcemija, bubrežna insuficijencija, intersticijalni nefritis i proteinurija retko se javljaju kod tuberkuloze pluće, ali ih treba razmatrati kao ozbiljne komplikacije. Stoga, hiperkalcemiju bi trebalo prvo kontrolisati hidratacijom ili steroidnim lekovima uz istovremeno lečenje tuberkuloze, kao i uvođenjem diuretika Henleove petlje i dijetetskog režima.

Ključne reči: hiperkalcemija, bubrežna insuficijencija, tuberkuloza 